\title{
Definition of the concepts of conventional and non-conventional projects
}

\author{
Anastasia N. Blaset Kastro \\ Consultant, Compulink Group \\ Address: 45, Michurinskiy Prospect, Moscow, 119607, Russian Federation \\ E-mail:anblaset@gmail.com \\ Nikolay Yu. Kulakov \\ Chief Financial Officer, Venta Investment \& Finance Company \\ Address: 31A, Leningradskiy Prospect, Moscow, 125284, Russian Federation \\ E-mail:nkulakov@gmail.com
}

\begin{abstract}
The term "non-conventional" project or "project with non-conventional cash flows" was introduced into economic literature after the internal rate of return (IRR) was shown to have multiple values or not exist at all in some projects. A project is considered to be conventional if it has only one change in the cash flow sign, no matter whether minus to plus or vice versa. A conventional project has a unique IRR. However, not all projects with a multiple sign change in cash flow are non-conventional, i.e. have problems with IRR determination. To ascertain the project type, the generally accepted approach recommends investigating monotony of the net present value (NPV) depending on the discount rate in order to find out how many IRRs the project has. On the other hand, neither the monotony of the NPV function nor a unique IRR guarantee that the project is conventional. The IRR is known to be a rate of return for a conventional investment project rather than a non-conventional project. Moreover, it was shown that the rate of return of a non-conventional project cannot be determined within the framework of the NPV method, and therefore the concept of profitability cannot be formulated. The recently proposed generalized net present value (GNPV) method allows us to determine the rate of return of a non-conventional project.

This paper presents a method to determine the rate of return for an investment project of any type and proves that in the case of a conventional project the rate of return is the IRR, while in the case of a non-conventional project it is the generalized internal rate of return (GIRR). The necessary and sufficient conditions of conventional and non-conventional projects have been formulated.
\end{abstract}

Key words: conventional investment project, non-conventional investment project, internal rate of return, net present value, generalized net present value.

Citation: Blaset Kastro A.N., Kulakov N.Yu. (2016) Definition of the concepts of conventional and nonconventional projects. Business Informatics, no. 2 (36), pp. 16-23. DOI: 10.17323/1998-0663.2016.2.16.23.

\section{Introduction}

$\mathrm{T}$ The term "non-conventional" / "non-normal" project or "project with non-conventional cash flows" was introduced in economic literature after it had been discovered that the internal rate of return (IRR) could not be used to assess project effectiveness (i.e. the $I R R$ is not the rate of return of a project in the classic sense). A project is considered to be conventional if its cash flows have only one change in sign, no matter whether minus to plus or plus to minus [1, 2]. According to this definition, all projects with cash flows having multiple changes in sign are automatically referred to as non-conventional projects. However, this cannot be justified from the methodological point of view: multiple changes in sign are a property (necessary condition) of non-conventional projects, but not a definition (attribute) allowing us to clearly differentiate between 
conventional and non-conventional projects. In order to determine the project type, the generally accepted approach recommends considering the property of the function $N P V(r)$ : its monotony and existence of a multiple-valued $I R R$ or absence of an IRR. However, neither monotony of the function $N P V(r)$ nor the unique realvalued $I R R$ is an attribute of a conventional project. This proposition is refuted by Gronchi [3] when describing a project with the following cash flows: $(-100,270,-270$, $170)$. This project has a monotonically decreasing function $N P V(r)$, a unique real value $I R R=70 \%$, but is not a conventional project ${ }^{1}$.

A sufficient condition is considered to be an attribute in logic and mathematics. Among the researchers who formulated a sufficient condition of a conventional project are de Faro \& Soares [4], Soper [5], Gronchi [3], Cannaday et al. [6], Bussey \& Eschenbach [7], Teichroew et al. [8], Bernhard [9], Hajdasinski [10], Hazen [11], Beaves [12], Lohmann [13], Kulakov \& Kulakova [14]. The majority of economists consider the same sign of the present (or future) value of a project at the rate equal to the IRR to be a sufficient condition of a conventional project [9-13]. Some economists believe that the project type depends on the discount rate. For example, Teichroew et al. [8] and Hazen [11] determine project region changes of the discount rate for a nonsimple project, where the projects are termed as a pure investment, mixed and pure financial regions. At the same time, Magni supposes that by choosing a discount rate in each period at discretion one can convert a conventional project into a non-conventional one [15]. In our opinion, this proposition is erroneous: the project type should not depend on the discount rate. Besides, the existence of different versions is based on the fact that there is no mathematical definition of conventional and non-conventional projects. To-date no criterion or necessary and sufficient condition identifying a project type has been formulated. This paper offers a solution to the problem in question.

It has long been recognized that non-conventional projects have problems with determination of the IRR as the rate of return of a project. However, it is the imperfections of the $N P V$ method that lie at the root of the problems with the $I R R[14,16]$. The rate of return of a non-conventional project cannot be determined within the framework of the $N P V$ method. Generalization of the $N P V$ to the $G N P V$ by using different rates when at- tracting and reinvesting funds instead of a single rate allows us to resolve the problems with the $N P V$ wrongly attributed to the IRR. In the next section, we formulate the mathematical formulae determining the rate of return for any project type, both conventional and nonconventional, and we prove that in the case of a conventional project the rate of return is the $I R R$, and in the case of a non-conventional project it is the GIRR [17]. After that, we define and formulate the necessary and sufficient condition for conventional and non-conventional projects. In the fifth section, we present examples of two types of projects with comments followed by conclusions.

\section{Determination of the rate of return of an investment project}

Since the IRR is the rate of return of a conventional project, it is necessary to start with the definition of the rate of return of an investment project. Bierman and Smidt have suggested the following definition: "The internal rate of return of a conventional investment represents the highest rate of interest an investor could afford to pay on debt without losing money if all funds to finance the investment were borrowed and the loan (principal and accrued interest) was repaid by application of the cash proceeds from the investment as they were earned" [18]. Based on this definition, the interest rate on a loan can be determined as follows: "The loan interest rate (rate of cost) represents the minimum rate of return of an external project in which the borrowed funds can be invested to generate sufficient income to repay the loan with the accrued interest".

In order to avoid excessive repetitions, we will consider only investment projects. First, let us take a simple project consisting of only two cash flows: negative $C F_{0}$ and positive $C F_{1}$. As the initial cash flow is negative $\left(C F_{0}<0\right)$, additional capital has to be raised to finance the project. Suppose a loan $S_{0}=-C F_{0}$ with an interest rate $\mathrm{r}$ per period is granted. After a period, the loan with the accrued interest will be equal to $S_{1}=S_{0}(1+r)$. The rate $r^{*}$ at which the total amount of debt will be equal to the income $C F_{1}$ is the rate of return of the investment project $S_{1}\left(r^{*}\right)=C F_{1}$, the rate $r^{*}$ being the highest interest rate an investor can afford without a loss. We next prove the proposition.

Proof: The function $S_{1}(r)$ monotonically increases as the discount rate increases because

\footnotetext{
${ }^{1}$ The cash flow considered by Gronchi is a special case project: $-A, A(2+r),-A(2+r), A(1+r)$, where $\mathrm{A}$ is the initial investment, and $r=I R R$. This project is non-conventional, because the present values changes sign: $P V_{3}=A(1+r)>0, P V_{2}=-A(2+r)+A==-A(1+r)<0, P V_{1}=A(2+r)-A=A(1+r)>0, P V_{0}=-A+A=0$.
} 


$$
\frac{d S_{1}}{d r}=S_{0}=-C F_{0}>0 .
$$

Indeed, for $\delta>0$ and $r=r^{*}+\delta$ we have: $S_{1}(r)-C F_{1}=$ $=S_{0}(1+r)-C F_{1}=S_{0}\left(1+r^{*}\right)+S_{0} \delta-C F_{1}=S_{0} \delta>0$. QED. The debt will not be repaid.

Now let us consider an investment project containing more than two cash flows. Let $C F_{i}$ be the project's cash flows in period $i$, where $i=0,1, \ldots, N$. Suppose that the flows are formed at the beginning of every period. If the project balance is negative in some period, a loan will be borrowed to finance the project, and the resulting debt (loan with accrued interest) is repaid at the beginning of the next period. Payments on the current debt are made from cash inflow or a new loan covering the previous debt and outflow of this period. Thus, the debt balance $S_{i}$ in period $i$ is determined as follows:

$$
\begin{gathered}
S_{0}=-C F_{0}, S_{i+1}= \begin{cases}-C F_{i+1}+S_{i}(1+r) & \text { if } S_{i} \geq 0, \\
-C F_{i+1}+S_{i} & \text { if } S_{i}<0,\end{cases} \\
i=0, \ldots, N-1,
\end{gathered}
$$

where $r-$ an interest rate.

Technically, the debt balance of the project corresponds to the investment stream [11], the negative unrecovered investment balance stream [7], the project balance [8], the capital invested [13]. It should be noted that no interest is charged on the negative debt balance. The rate $r^{*}$ at which the debt will be repaid at the end of the project $S_{N}\left(r^{*}\right)=0$ is the rate of return of the project. Let us prove that $r^{*}$ is the highest and unique rate. We will calculate a derivative of the debt balance for every period from the beginning to the end of the project. In period 1 we have:

$$
\frac{d S_{1}}{d r}=S_{0}=-C F_{0}>0 .
$$

In period $i$ :

$$
\frac{d S_{i}}{d r}=\frac{d}{d r}\left(-C F_{i}+S_{i-1}(1+r)\right)=S_{i-1} .
$$

Let the debt balance be positive in every period from 0 to $i-1$, and negative in period $i$.

As $S_{i}=-C F_{i}+S_{i-1}(1+r)<0$ then $S_{i+1}=-C F_{i+1}+S_{i}$.

Let us calculate a derivative of the debt balance in period $i+1$ :

$$
\frac{d S_{i+1}}{d r}=\frac{d}{d r}\left(-C F_{i+1}+S_{i}\right)=\frac{d}{d r}\left(-C F_{i}+S_{i-1}(1+r)\right)=S_{i-1}>0 .
$$

By calculating the debt balance derivative for subsequent periods until the end of the project, we will obtain

$$
\frac{d S_{N}}{d r}=\frac{d}{d r}\left(-C F_{N}+S_{N-1}(1+r)\right)=S_{N-1}>0 .
$$

Therefore, the debt balance $S_{N}(r)$. is a monotonically increasing function of an interest rate $r$; so if the equation $S_{N}(r)=0$ has a solution, then the solution is unique. For a solution to exist, the sum of all cash flows has to be positive, in which case the debt balance at a zero interest rate will be negative.

$$
S_{N}(0)=-\sum_{i=0}^{N} C F_{i}<0
$$

(Corollary of the Intermediate Value Theorem).

Thus, the definition of the rate of return of an investment project is as follows: Let $C F_{i}$ where $i=0,1, \ldots, N$ be the project's cash flows. If there exists a rate $r^{*}$ such that $-1<r^{*}<\infty$ and the following conditions hold:

$S_{0}=-C F_{0}$

$S_{i+1}=\left\{\begin{array}{ll}-C F_{i+1}+S_{i}\left(1+r^{*}\right) & \text { if } S_{i} \geq 0, \\ -C F_{i+1}+S_{i} & \text { if } S_{i}<0,\end{array} \quad i=0, \ldots, N-1\right.$

$S_{N}\left(r^{*}\right)=0$

then rate $r *$ is the rate of return of the investment project.

The given definition is suitable for both conventional and non-conventional projects. We can now go on to define a conventional project.

The definition of a conventional project: If the IRR is the rate of return of an investment project, then the project is conventional. The converse is also true: if the project is conventional, the IRR is its rate of return.

Although the above definition is not new, it enables us to formulate a necessary and sufficient condition for the conventional project, namely: for the IRR to be the rate of return of an investment project, it is necessary and sufficient that all project present values discounted by the IRR should be positive in every period except the initial one.

\section{Necessary and sufficient conditions signifying that a given project is conventional (the IRR is its rate of return)}

\subsection{Sufficient condition}

Let $C F_{i}$ be project's cash flows, where $C F_{0}<0$ and $\Sigma C F_{i}>0, i=0,1, \ldots, N$. If for $\forall i$ there exists $-1<r<\infty$ and the following conditions hold:

$$
\begin{aligned}
& P V_{i+1}>0, \text { where } \\
& P V_{N}=C F_{N}, P V_{i}=\frac{P V_{i+1}}{1+r}+C F_{i}, \\
& N P V(r)=P V_{0}(r)=0 .
\end{aligned}
$$

Then the discount rate $r$ is the rate of return of the project and the project is conventional. 
Proof: We will calculate a derivative of the present value with respect to the discount rate. The derivative of the present value at time $i$ with respect to rate $r$ is equal to:

$$
\begin{gathered}
\frac{d P V_{N}}{d r}=\frac{d C F_{N}}{d r}=0, \quad i=N, \\
\frac{d P V_{i}}{d r}=\frac{d}{d r}\left(\frac{P V_{i+1}}{1+r}+C F_{i}\right)=\left(-\frac{P V_{i+1}}{1+r}+\frac{d P V_{i+1}}{d r}\right) \frac{1}{1+r}, \\
i=N-1, \ldots, 0 .
\end{gathered}
$$

Thus, if for $\forall i P V_{i+1}>0$, then the derivative $\frac{d P V_{i}}{d r}<0$, consequently the function $P V_{i}(r)$ monotonically decreases as the rate $r$ increases. Continuing the calculation until time $i=0$, we get $\frac{d N P V(r)}{d r}<0$. Thus, the $N P V(r)$ monotonically decreases as the discount rate increases. Therefore, the equation $N P V(I R R)=0$ can have a single real root.

Note that $r^{*}$ from the equation $S_{N}\left(r^{*}\right)=0$ (2.3) coincides with (is the same as) the IRR. It is evident that $S_{N}\left(r^{*}\right)=-N P V\left(r^{*}\right)\left(1+r^{*}\right)^{N}$. So, if $N P V_{0}\left(r^{*}\right)=0$, then $S_{N}\left(r^{*}\right)=0$. Therefore, if conditions (3) are met, the IRR is the project's rate of return.

\subsection{Necessary condition}

Let $C F_{i}$ be the project's cash flows, where $i=0,1, \ldots, N$ and the project's $I R R$ be its rate of return. Then we have

$$
\begin{gathered}
N P V\left(r^{*}\right)=\sum_{i=0}^{N} \frac{C F_{i}}{\left(1+r^{*}\right)^{i}}=0 \text { and } \\
S_{N}\left(r^{*}\right)=-N P V\left(r^{*}\right)\left(1+r^{*}\right)^{N}=0 .
\end{gathered}
$$

Let us prove that for

$$
\forall i<N: S_{i}\left(r^{*}\right) \geq 0 .
$$

Proof: Let $\exists k \neq N$ for which $S_{k}\left(r^{*}\right)<0$ then:

$$
\begin{gathered}
S_{k+1}=-C F_{k+1}+S_{k} \Rightarrow S_{N}= \\
=-\sum_{i \neq k}^{N} C F_{i}\left(1+r^{*}\right)^{N-i} \Rightarrow S_{N}\left(r^{*}\right)=f\left(\left(1+r^{*}\right)^{N-1}\right) .
\end{gathered}
$$

But then the equation $S_{N}\left(r^{*}\right)=-N P V\left(r^{*}\right)\left(1+r^{*}\right)^{N}$ is wrong. Therefore, every $S_{i}$ should be positive.

The proof provided of a necessary condition perhaps is not strict enough to define a non-conventional project. Another proof can be found in [19].

The definition of a non-conventional project: Replacing "is" with "is not" might seem logical: If the $I R R$ is not the rate of return of an investment project, then the project is non-conventional. However, the IRR may not exist either at all or in a given interval of the discount rate range. This case will be considered in the next sec- tion of the paper. Let us now consider a case when the IRR does exist.

Necessary and sufficient conditions signifying that a given project is non-conventional:

Let us have a project with cash flows $C F_{i}$, where $i=0, \ldots, N, N \geq 3$ and the following conditions hold:

If for $0<r<\infty \exists i, j \in N, \ldots, 1 ;(i \neq j)$ so that:

$$
P V_{i} \geq 0 \text { and } P V_{j}<0 \text {, where }
$$

$$
P V_{N}=C F_{N}, P V_{i}=\frac{P V_{i+1}}{(1+r)}+C F_{i}, P V_{0}(r)=0
$$

Then the project is non-conventional.

The $N P V(r)$ is a function of the $N$ th degree of the discount rate $r$. However, the debt balance function $S_{N}(r)$ will have the maximum power of $r$ which is less than $N$ according to (4). Therefore, the rate $r$ defined by conditions (5) is not the rate of return.

The converse is also true: If $r^{*} \neq I R R$ then $\exists P V_{i}<0$.

Proof: According to conditions $N P V(I R R)=0$, $N P V(I R R) \cdot(1+I R R)^{N}=0$, since $I R R \neq-1$. Let us assume that for $\forall i P V_{i}(I R R)>0$. Then

$$
\begin{gathered}
0=N P V(I R R) \cdot(1+I R R)^{N}=\sum_{i=0}^{N} \frac{C F}{(1+I R R)^{i}}(1+I R R)^{N}= \\
=\sum_{i=0}^{N} C F_{i}(1+I R R)^{N-i}=-S_{N}(I R R)=0 .
\end{gathered}
$$

But $r *$ from (2) is not equal to the $I R R$, which means that $S_{N}(I R R) \neq 0$; as a result, we have got a contradiction of $\exists k$ for which $P V_{k}(I R R)<0$.

Unfortunately, it is impossible to use this definition in the case when the non-conventional project has no the $I R R$. Nevertheless, the rate of return of the non-conventional project does exist and can be defined in terms of the $G N P V$ method.

\section{Generalizing the NPV (the GNPV method)}

Several researchers point out the advantages [16] and even justify [17] the application the $N P V$ method to non-conventional projects. Kulakov and Kulakova [14] have recently proposed the $G N P V$ method, which generalizes the $N P V$ method by using two discount rates (finance and reinvestment).

The $G N P V$ function is determined by consistently discounting cash flows from the end to the beginning of the project. If the present value of the project in a certain period is positive, we use the internal discount rate, otherwise - the external one. The internal rate determines 
the cost of funding an investment, and the external rate determines the return on the investment. The GNPV function is determined as follows [14]:

$P V_{N}=C F_{N}$

$P V_{i}=\left\{\begin{array}{l}\frac{P V_{i+1}}{(1+r)}+C F_{i}, \text { if } P V_{i+1}>0, \\ \text { otherwise } \\ \frac{P V_{i+1}}{(1+p)}+C F_{i}, \text { where } i=N-1, \ldots, 0 ;\end{array}\right.$

$G N P V(r, p)=P V_{0}$

where $C F_{i}$ is the project's cash flow in period $i$, $(i=N, \ldots, 0) ; P V_{i}$ is the project's present value in period $i ; r$ and $p$ are the internal and the external discount rate, respectively.

To find the roots of the GNPV function it is necessary to solve the equation:

$$
\operatorname{GNPV}(r, p)=0
$$

The solution of this equation can be sought in the form of $r=r(p)$ or $p=p(r)$ depending on the purpose of nonconventional project evaluation. The GIRR is a rate of return and represents the maximum interest rate on the loan borrowed to finance the project, with the resulting income of the current project used to repay the principal amount and the accrued interest. The $\operatorname{GIRR}(p)$ is the function of the reinvestment rate $p$. The GERR $(r)$ is a rate of cost and represents the minimum rate of return of an external project in which the borrowed funds can be invested to generate sufficient income to repay the loan with the accrued interest.

The systems of the equations (2) are equivalent to (6-7) if rate $p$ is equal to 0 .

\section{Discussion}

Let us consider several projects using the above approach.

\subsection{A project}

(cash flows change sign more than once)

Let us consider a project with cash flows having multiple changes in sign (Table 1).

\section{A conventional project}

\begin{tabular}{l|c|c|c|c}
\hline Period & 0 & 1 & 2 & 3 \\
\hline Cash flows & -100.0 & 111.7 & -90.0 & 120.0 \\
\hline$N P V$ at $\boldsymbol{r}=20 \%$ & 0.0 & 120.0 & 10.0 & 120.0 \\
\hline $\operatorname{GNPV}(\boldsymbol{r}, 0)$ & 0.0 & 120.0 & 10.0 & 120.0 \\
\hline
\end{tabular}

Although the cash flows change sign more than once, the project's $I R R$ is unique and equal to $20 \%$. As all project present values are positive in every period except the initial one, the project is conventional.

The highest loan interest rate $r^{*}$ at which the project income covers the loan and accrued interests without loss is $20 \%$ per year (Table 2). Therefore $r *$ is the rate of return of the project. The IRR is equal to $r^{*}$, so the project is conventional.

Table 2.

Cash flow statement

(the loan interest rate is 20\%)

\begin{tabular}{l|c|c|c|c}
\hline Period & 0 & 1 & 2 & 3 \\
\hline Operating & $\mathbf{0}$ & $\mathbf{9 1 . 7}$ & $\mathbf{- 1 . 7}$ & $\mathbf{1 0 0 . 0}$ \\
\hline Interest payments & 0 & -20.0 & -1.7 & -20.0 \\
\hline Cash received from project & 0 & 111.7 & 0 & 120.0 \\
\hline Investing & $\mathbf{- 1 0 0}$ & $\mathbf{0}$ & $\mathbf{- 9 0 . 0}$ & \\
\hline Cash paid to project & -100 & 0 & -90.0 & \\
\hline Financing & $\mathbf{1 0 0}$ & $\mathbf{- 9 1 . 7}$ & $\mathbf{9 1 . 7}$ & \\
\hline Borrowing loan & 100 & 0 & 91.7 & \\
\hline Loan repayment & 0 & -91.7 & 0 & -100.0 \\
\hline Debt balance & $\mathbf{1 0 0}$ & $\mathbf{8 . 3}$ & $\mathbf{1 0 0 . 0}$ & $\mathbf{0 . 0}$ \\
\hline \multicolumn{5}{|l}{}
\end{tabular}

\subsection{Two similar projects of different type}

Let us consider two similar projects (Table 3, Table 4), which have the same changes in sign and cash flows in every period except the last one.

Table 3.

\section{A conventional project}

\begin{tabular}{l|c|c|c|c}
\hline Period & 0 & 1 & 2 & 3 \\
\hline Cash flows & -100.0 & 120.0 & -100.0 & 120.0 \\
\hline$N P V$ at $r=20 \%$ & 0.0 & 120.0 & 0.0 & 120.0 \\
\hline $\operatorname{GNPV}(\boldsymbol{r}, 0)$ & 0.0 & 120.0 & 0.0 & 120.0 \\
\hline
\end{tabular}

The project's $I R R$ is unique and equal to $20 \%$. As all project present values are not negative in every period, the project is conventional.

Table 4.

A non-conventional project

\begin{tabular}{l|c|c|c|c}
\hline Period & 0 & 1 & 2 & 3 \\
\hline Cash flows & -100.0 & 120.0 & -100.0 & 110.0 \\
\hline NPV at $\boldsymbol{r}=15.7 \%$ & 0.0 & 115.7 & -4.9 & 110.0 \\
\hline GNPV $(15,4 \%, 0)$ & 0.0 & 115.4 & -4.6 & 110.0 \\
\hline
\end{tabular}

The IRR of the project is equal to $15.73 \%$. The present value in period 2 is negative therefore the project is nonconventional. Table 5 presents the calculation of the highest loan interest rate $r^{*}$ at which the project income covers 
the loan and accrued interests without loss. As the rate $r *$ is $15.4 \%$ and is not equal to the $I R R$, the project is non-conventional. While the $\operatorname{GIRR}(0)=15.4 \%$ is the same as $r^{*}$.

Table 5 .

Cash flow statement (loan interest rate is $\mathbf{1 5 . 4 \% )}$

\begin{tabular}{l|c|c|c|c}
\hline Period & 0 & 1 & 2 & 3 \\
\hline Operating & $\mathbf{0}$ & $\mathbf{1 0 4 . 6}$ & $\mathbf{0 . 0}$ & $\mathbf{9 5 . 4}$ \\
\hline Interest payments & 0 & -15.4 & 0.0 & -14.6 \\
\hline Cash received from project & 0 & 120.0 & 0 & 110.0 \\
\hline Investing & $\mathbf{- 1 0 0}$ & $\mathbf{0}$ & $\mathbf{- 1 0 0}$ & $\mathbf{0}$ \\
\hline Cash paid to project & -100 & 0 & -100 & 0 \\
\hline Financing & $\mathbf{1 0 0}$ & $\mathbf{- 1 0 0 . 0}$ & $\mathbf{9 5 . 4}$ & $\mathbf{- 9 5 . 4}$ \\
\hline Borrowing loan & 100 & 0 & 95.4 & 0 \\
\hline Loan repayment & 0 & -100.0 & 0 & -95.4 \\
\hline Debt balance & $\mathbf{1 0 0}$ & $\mathbf{0}$ & $\mathbf{9 5 . 4}$ & $\mathbf{0}$ \\
\hline
\end{tabular}

\subsection{A project without IRR}

Let us consider a non-conventional project without an IRR (Table 6).

\section{A non-conventional project without an IRR}

\begin{tabular}{l|c|c|c}
\hline Period & 0 & 1 & 3 \\
\hline Cash flows & -100.0 & 195.0 & -100.0 \\
\hline NPV at $r=-5 \%$ (no the IRR) & -5.5 & 89.7 & -100.0 \\
\hline GNPV $(-5 \%, 0)$ & 0.0 & 95.0 & -100.0 \\
\hline
\end{tabular}

As the project does not have an $I R R$, it is non-conventional.

Table 7.

Cash flow statement (the loan interest rate is $\mathbf{- 5 \%}$ )

\begin{tabular}{l|c|c|c}
\hline Period & 0 & 1 & 2 \\
\hline Operating & $\mathbf{0}$ & $\mathbf{2 0 0 . 0}$ & $\mathbf{0}$ \\
\hline Interest payments & 0 & 5.0 & 0 \\
\hline Cash received from project & 0 & 195.0 & 0 \\
\hline Investing & $\mathbf{- 1 0 0}$ & $\mathbf{0}$ & $\mathbf{- 1 0 0}$ \\
\hline Cash paid to project & -100 & 0 & -100 \\
\hline Financing & $\mathbf{1 0 0}$ & $\mathbf{- 1 0 0 . 0}$ & $\mathbf{0}$ \\
\hline Borrowing loan & 100 & 0 & 0 \\
\hline Loan repayment & 0 & -100.0 & 0 \\
\hline Debt balance & $\mathbf{1 0 0}$ & $\mathbf{0}$ & $\mathbf{0}$ \\
\hline
\end{tabular}

The loan interest rate $r^{*}$ at which the project income covers the project outflows is $-5 \%$ (Table 7$)$. Therefore $r^{*}$ is the rate of return of the project. An IRR does not exist, while the $\operatorname{GIRR}(0)=-5 \%$ is the same as $r^{*}$.

\section{Conclusion}

Generally, all projects with cash flows having multiple changes in sign are referred to as non-conventional projects. That is just a property, but not a definition of a non-conventional project. Most economists consider the same sign of the present (or future) value of a project at the rate equal to the $I R R$ to be a sufficient condition (attribute) of a conventional project. However, the determination of conventional and non-conventional projects has not been formulated yet.

It is known that non-conventional projects have problems with determination of $I R R$ (a multiple-valued $I R R$ or no real-valued $I R R$ at all). On the other hand, if a project has a single $I R R$, this does not mean that the project in question is conventional. The $I R R$ for a conventional project is its rate of return. Therefore, it is logical to conclude with a definition that the project is conventional if the $I R R$ is the rate of return, and conversely, if the $I R R$ is not the rate of return, the project is non-conventional. However, the rate of return of a nonconventional project cannot be determined within the framework of the $N P V$ method. Generalization of the $N P V$ to the $G N P V$ by using two different rates when attracting and reinvesting funds instead of a single rate allows us to determine the rate of return of a non-conventional project.

This paper presents a mathematical determination of the rate of return for an investment project of any type and proves that in the case of a conventional project the rate of return is the $I R R$, while in the case of a nonconventional project it is the GIRR. The necessary and sufficient conditions of the conventional and non-conventional projects have been formulated. We hope that application of the proposed methodology to investment project profitability assessment will simplify calculation processes and help to avoid possible errors resulting from the imperfections of the $N P V$ method.

\section{References}

1. Brealey R.A., Myers S.C. (2003) Principles of corporate finance. 7th Ed. New York: McGraw-Hill.

2. Brigham E.F., Gapenski L.C. (1996) Intermediate financial management. Orlando, FL: Dryden Press.

3. Gronchi S. (1986) On investment criteria based on the internal rate of return. Oxford Economic Papers, no. 38 (1), pp. 174-180.

4. De Faro C., Soares L. (1978) A flexible sufficient condition for a unique non-negative internal rate of return. The Engineering Economist, no. 23 , pp. $117-127$.

5. Soper C.S. (1959) The marginal efficiency of capital: A further note. The Economic Journal, no. 69 (273), pp. 174-177.

6. Cannaday R.E., Colwell P.F., Paley H. (1986) Relevant and Irrelevant internal rates of return. The Engineering Economist, no. 32, pp. 17-38. 
7. Bussey L.E., Eschenbach T.G. (1992) The economic analysis of industrial projects, 2nd Ed. New Jersey: Prentice-Hall.

8. Teichroew D., Robichek A.A., Montalbano M. (1965) An analysis of criteria for investment and financing decisions under certainty Management Science, no. 12 (3), pp. 150-179.

9. Bernhard R.H. (1979) A simpler internal rate of return uniqueness condition which dominates that of de Faro and Soares. The Engineering Economist, no. 24 (2), pp. 71-74.

10. Hajdasinski M.M. (1987) On relevant and irrelevant internal rates of return. The Engineering Economist, no. 32, pp. 347-353.

11. Hazen G.B. (2003) A new perspective on multiple internal rates of return. The Engineering Economist, no. 48, pp. 31-51.

12. Beaves R.G. (1988) Net present value and rate of return: Implicit and explicit reinvestment assumptions. The Engineering Economist, no. 33 (4), pp. 275-302.

13. Lohmann J.R. (1988) The IRR, NPV and the fallacy of the reinvestment rate assumption. The Engineering Economist, no. 33 (4), pp. 303-330

14. Blaset Kastro (Kulakova) A.N., Kulakov N.Yu. (2013) Evaluation of non-conventional projects. The Engineering Economist, no. 52 (2), pp. 137-148.

15. Magni C.A. (2010) Average internal rate of return and investment decisions: A new perspective. The Engineering Economist, vol. 55, no. 2, pp. $150-181$.

16. Eschenbach T.G., Nicholls G.M. (2012) Is PW useful for the lorie-savage oil pump problem? Proceedinggs of the IIE Annual Conference \& Expo 2012, ISERC, 19-23 May 2012, Orlando, Florida.

17. Blaset Kastro (Kulakova) A.N., Kulakov N.Yu. (2012) Capital budgeting technique for non-conventional projects. Proceedings of the IIE Annual Conference \& Expo 2012, ISERC, 19-23 May 2012, Orlando, Florida.

18. Bierman H. (Jr.), Smidt S. (1993) The capital budgeting decision, 8th ed. New York: MacMillan.

19. Dearing D., Richard V.H. (2010) Project balances as division coefficients and implications for rate of return analysis. The Engineering Economist, vol. 55, no. 2, pp. 38-51.

\section{Определения типичного и нетипичного проектов}

\section{А.Н. Бласет Кастро}

кандидат экономических наук, консультант, Группа компаний «КомпьюЛинк»

Адрес: 119607, г. Москва, Мичуринский проспект, д. 45

E-mail:anblaset@gmail.com

\section{Н.Ю. Кулаков}

кандидат технических наук, финансовый директор, Инвестиционно-финансовая компания «Вента»

Адрес: 125284, г. Москва, Ленинградский проспект, д. 31A, стр.1

E-mail: nkulakov@gmail.com

\section{Аннотация}

Понятие «нетипичный», «нестандартный» проект или «проект с нетипичными денежными потоками» введено в экономическую литературу после того, как было показано, что для некоторых проектов внутренняя нома доходности (internal rate of return, IRR) может иметь несколько значений или не существовать вовсе. Проект считается «типичным», если его денежный поток только один раз меняет знак, независимо от направления: с минуса на плюс или наоборот. Типичный проект имеет единственное значение IRR. Oднако не все проекты с многократным изменением знака денежного потока являются «нетипичными», т.е. имеют проблемы с определением IRR. Поэтому теория рекомендует для определения типа проекта исследовать зависимость функции чистого дисконтированного дохода (net present value, NPV) от ставки дисконтирования на монотонность с целью выявления множественности или отсутствия IRR. С другой стороны, монотонность NPV и единс венное значение IRR не гарантируют того, что проект типичный. Более того, было показано, что доходность нетипичного проекта в рамках подхода NPV не может быть определена, а, следовательно, и понятие доходности не может быть сформулировано. Недавно был предложен метод обобщенной чистой приведенной стоимости (generalized net present value, GNPV), на основе которого может быть рассчитана доходность «нетипичного» проекта.

В данной статье сформулировано понятие доходности для инвестиционного проекта любого типа и доказана ее тождественность обобщенной внутренней норме доходности (generalized internal rate of return, GIRR), вытекающей из метода GNPV. Дается определение и формулируются необходимое и достаточное условия типичного и нетипичного проекта. 
Ключевые слова: типичный инвестиционный проект, нетипичный инвестиционный проект, внутренняя норма доходности, чистый дисконтированный доход, обобщенный чистый дисконтированный доход.

Цитирование: Blaset Kastro A.N., Kulakov N.Yu. Definition of the concepts of conventional and non-conventional projects // Business Informatics. 2016. No. 2 (36). P. 16-23. DOI: 10.17323/1998-0663.2016.2.16.23.

\section{Литература}

1. Brealey R.A., Myers S.C. Principles of corporate finance. 7th Ed. New York: McGraw-Hill, 2003.

2. Brigham E.F., Gapenski L.C. Intermediate financial management. Orlando, FL: Dryden Press, 1996.

3. Gronchi S. On investment criteria based on the internal rate of return // Oxford Economic Papers. 1986. No. 38 (1). P. 174-180.

4. De Faro C., Soares L. A flexible sufficient condition for a unique non-negative internal rate of return // The Engineering Economist. 1978. No. 23. P. $117-127$.

5. Soper C.S. The marginal efficiency of capital: A further note // The Economic Journal. 1959. No. 69 (273). P. 174-177.

6. Cannaday R.E., Colwell P.F., Paley H. Relevant and Irrelevant internal rates of return // The Engineering Economist. 1986. No. 32. P. 17-38.

7. Bussey L.E., Eschenbach T.G. The economic analysis of industrial projects. 2nd Ed. New Jersey: Prentice-Hall, 1992.

8. Teichroew D., Robichek A.A., Montalbano M. An analysis of criteria for investment and financing decisions under certainty // Management Science. 1965. No. 12 (3). P. 150-179.

9. Bernhard R.H. A simpler internal rate of return uniqueness condition which dominates that of de Faro and Soares // The Engineering Economist. 1979. No. 24 (2). P. 71-74.

10. Hajdasinski M.M. On relevant and irrelevant internal rates of return // The Engineering Economist. 1987. No. 32. P. $347-353$.

11. Hazen G.B. A new perspective on multiple internal rates of return // The Engineering Economist. 2003. No. 48. P. 31-51.

12. Beaves R.G. Net present value and rate of return: Implicit and explicit reinvestment assumptions // The Engineering Economist. 1988. No. 33 (4). P. 275-302.

13. Lohmann J.R. The IRR, NPV and the fallacy of the reinvestment rate assumption // The Engineering Economist. 1988. No. 33 (4). P. $303-330$.

14. Blaset Kastro (Kulakova) A.N., Kulakov N.Yu. Evaluation of non-conventional projects // The Engineering Economist. 2013. No. 52 (2). P. $137-148$.

15. Magni C.A. Average internal rate of return and investment decisions: A new perspective // The Engineering Economist. 2010. Vol. 55. No. 2. P. $150-181$.

16. Eschenbach T.G., Nicholls G.M. Is PW useful for the lorie-savage oil pump problem? // Proceedinggs of the IIE Annual Conference \& Expo 2012, ISERC, 19-23 May 2012, Orlando, Florida.

17. Blaset Kastro (Kulakova) A.N., Kulakov N.Yu. Capital budgeting technique for non-conventional projects // Proceedings of the IIE Annual Conference \& Expo 2012, ISERC, 19-23 May 2012, Orlando, Florida.

18. Bierman H. (Jr.), Smidt S. The capital budgeting decision. 8th ed. New York: MacMillan, 1993.

19. Dearing D., Richard V.H. Project balances as division coefficients and implications for rate of return analysis // The Engineering Economist. 2010. Vol. 55. No.2. P. 38-51. 